\title{
FOREIGN DIRECT INVESTMENTS IN THE WORLD WITH SPECIAL CONSIDERATION OF CONSEQUENCES
}

\author{
Grzegorz Górniewicz' ${ }^{1}$ Adrianna Czarnecka²
}

\begin{abstract}
This paper describes the key phenomenon occurring in the contemporary world economy, which is foreign direct investments. The paper focuses mostly on the scale of FDI flow in the world. Furthermore, much attention was paid to the determinants of the inflow of investments and to their economic consequences.
\end{abstract}

Key words: foreign direct investments, determinants, consequences.

JEL Classification: $\mathrm{O33}$

\section{Introduction}

In the last decades, one can observe the dynamic growth of the international flows of the means of production. The ever-lasting globalization processes will probably stimulate the said phenomenon in the future. The international flows of the means of production include mainly international capital flow, workforce and knowledge. Theoretically speaking, one could possibly distinguish international flow of land*. Yet, nowadays, the last possibility is not exemplified. The international capital flow embraces what follows: foreign and portfolio loans and foreign direct investments, the latter of which is the subject of the present paper.

A important reason for international flow of the means of production, including foreign direct investments, is the possibility of bigger profit abroad than in one's native country. Furthermore, the key role is definitely played by the opportunity to make use of the resources (mainly capital and human resources) for which there is no demand on one's native market.

The main purpose of this paper is to demonstrate the disproportions in the world allocation of foreign direct investments. Furthermore, the paper presents the causes of FDI flows and their consequences.

\section{Definition}

The primary literature on the subject presents a plethora of definitions of the concept of foreign direct investments. Among them, there is the paradigmatic definition of foreign direct investment, which was worked out by Organization for Economic Cooperation and Development (OECD). According to its definition, the foreign investment is a business enterprise in which one foreign investor acquires or is in the possession of long-lasting share as expressed by having at least $10 \%$ of equities of that enterprise or $10 \%$ of votes at the annual general meeting of shareholders, which according to OECD yields an efficient influence on managing a business enterprise (OECD, 2008, p. 17).

Another oft-cited definition, broader though compatible with the above-stated one, is the definition by the International Monetary Fund. It assumes the following form: the direct investment is an investment made for the sake of obtaining the long-lasting share in the business enterprise operating in the economy other than the native economy of the very investor, while the aim of the investor is to obtain the efficient influence on managing the enterprise (Jasiński, Mesjasz, 1997, p. 34). As can be noted, that definition does not specify the lower threshold of the shares in a given enterprise yielding the efficient influence on the decisions made in it. Some authors try to stipulate their own definitions, which, essentially, to a large degree overlap with the definitions presented above.

An enterprise investing in the form of FDI can be: - subsidiaries - when the investor has over $50 \%$ of votes at the general meeting of shareholders;

- an associate - then the investor has $10-50 \%$ of voting rights;

\footnotetext{
Corresponding author:

${ }^{1}$ WSB University in Gdańsk, Poland.

E-mail: ggorniewicz@wsb.gda.pl

ORCID: https://orcid.org/0000-0001-6384-3716

${ }^{2}$ Nicolaus Copernicus University in Torun, Poland.

ORCID: https://orcid.org/0000-0002-1879-4924
}

\footnotetext{
* The most spectacular instance of such a flow was the purchase of Alaska by USA from Russia made in 1867. A bit sooner (in 1819), USA bought Florida from Spain.
} 
- quasi-corporate - in the form of a branch which is $100 \%$ connected with the parent corporation (Redo, Siemiątkowski, 2017, p. 35).

Among foreign direct investments, one can distinguish the ones of greenfield, brownfield and acquisitions type. The former are the investments created from scratch. They involve building completely new business enterprises. Greenfield ones characterize mainly the developing countries. On the other hand, brownfield-type investments occur mainly in the highly developed countries. They involve taking over the enterprises being already in existence or they assume the form of a merger (Górniewicz, 2007, p. 13). Acquisitions consist in investing cash in already existing foreign entities. Therefore, a foreign investor takes control over an entity located in another country (Redo, Siemiątkowski, 2017, p. 36).

\section{Statistical data}

According to the data in Investment Trends Monitor foreign direct investments amounted to 1,39 trillion dollars in the whole world in 2019 (see diagram 1). The best result in the last several years was achieved in 2007. Then DFI exceeded 2 trillion dollars. Generally speaking, one must say that the decrease in foreign direct investments on the turn of the first and second decade of XXI century resulted from the collapse of the mortgage loan market caused by the bursting of speculative bubble on the property market in U.S.A in August 2007 initiated the world economic crisis. It is commonly considered the greatest recession since the times of Great Depression within 1929-1933.
In recent years, most FDI has been located in the USA. In 2018, they were over 250 billion dollars. The next places were: China (almost 140 billion dollars), Hong Kong (116 billion dollars), Singapore (78 billion dollars) and Netherlands (70 billion dollars). Detailed data is presented in diagram 2. In 2018, most investments were received in developing countries (54.5\%). 42.9\% was located in developed countries, and $2.6 \%$ of all FDIs in countries referred to as transition economies.

FDI flows were affected by the following trends in the global economy:

- FDI in the United Kingdom down 6\% as Brexit unfolds;

- Hong Kong, China divestments cause a 48\% FDI decline among turbulence;

- Singapore up $42 \%$ in a buoyant ASEAN region;

- zero-growth of flows to both the United States and China;

- Brazil up 26\% at the start of a privatization programme; - German inflows triple as MNEs extend loans to foreign affiliates in a year of slow growth (Investment Trends Monitor, 2020, p. 2).

In 2018, most FDI came from Japan (143 billion dollars), China (130 billion dollars) and France (102 billion dollars). Detailed data is presented in diagram 3. Interestingly, the United States disappeared from the list of the world's largest investors, which in 2017 was definitely in first place with a result of 342 billion dollars.

Analyzing the industry structure, one must note that in the world flows of foreign direct investments, it is the services that predominate. Services encompass

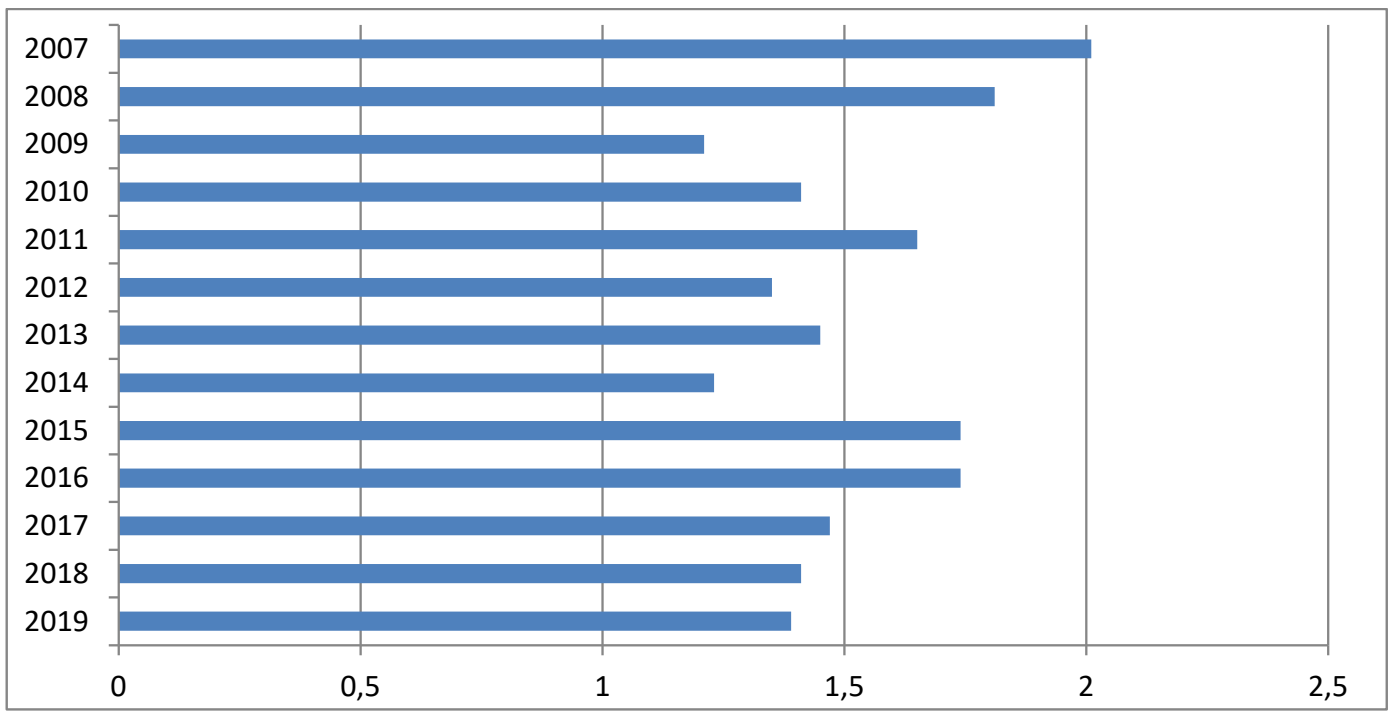

Diagram 1. Global flows of FDI (in trillions of dollars)

Source: my own lay-out on the basis of World Investment Report 2013: Global Value Chains: Investment and Trade for Development, United Nations, New York and Geneva 2013, pp. 213 - 216; World Investment Report 2015. Reforming International Investment Governance, United Nations, New York and Geneva 2015, p. 4 and Investment Trends Monitor, https://unctad.org/en/PublicationsLibrary/diaeiainf2020d1_en.pdf[2020.05.03] 


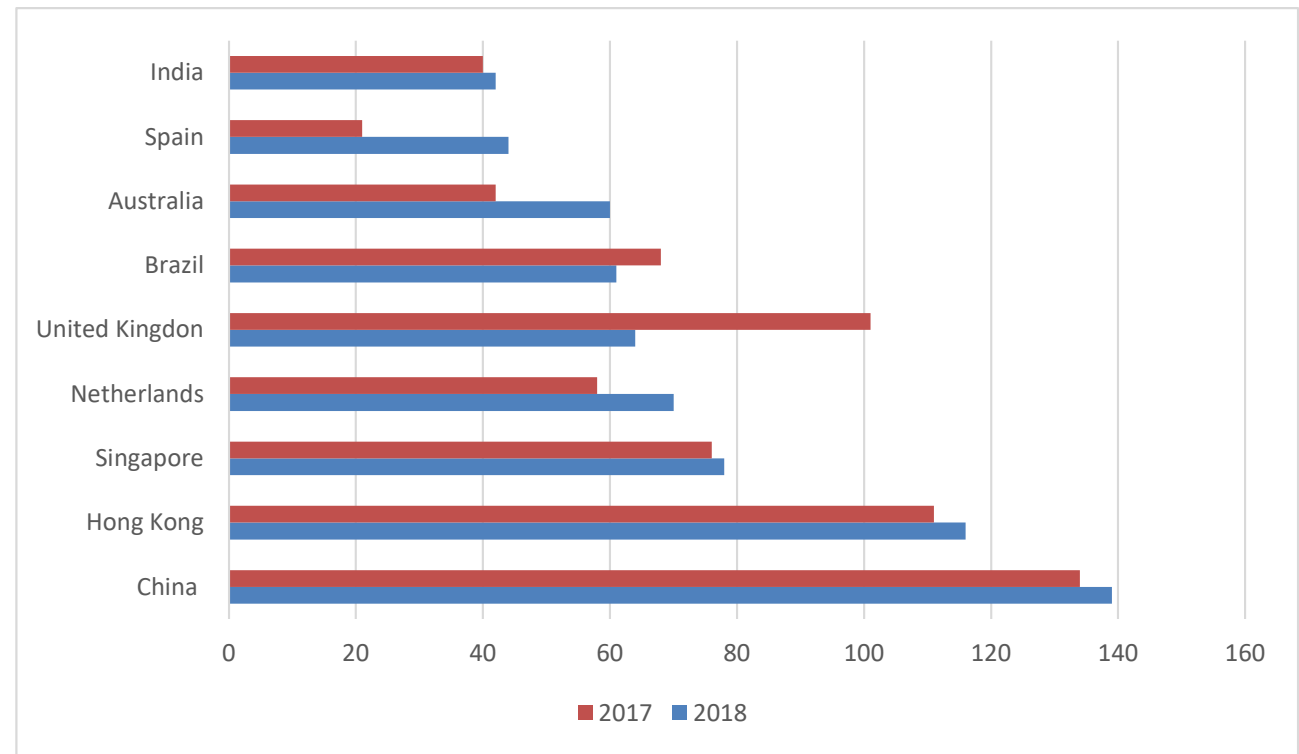

Diagram 2. FDI inflows in 2018 year (in billions of dollars)

Source: my own lay-out on the basis of World Investment Report 2019. Key Messages and Overview. Geneva: United Nations, p. 3

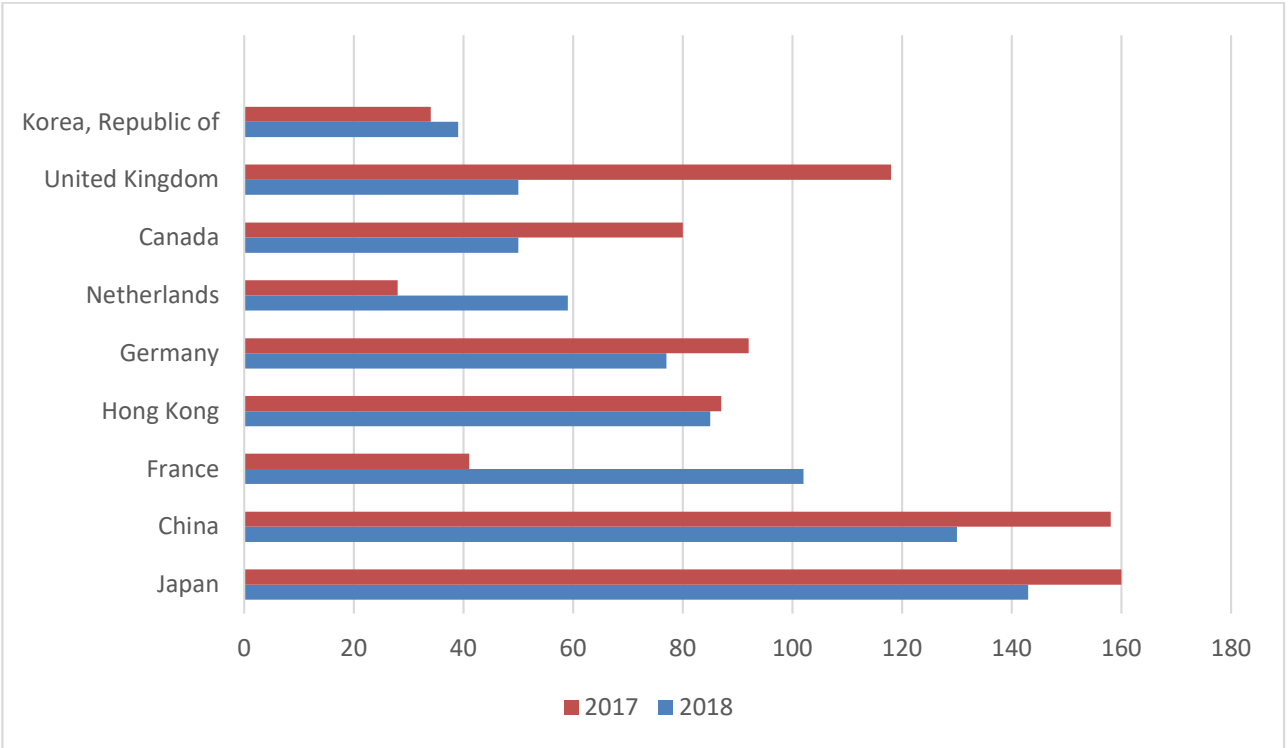

Diagram 3. FDI outflows in 2018 year (in billions of dollars)

Source: my own lay-out on the basis of World Investment Report 2019. Key Messages and Overview. Geneva: United Nations, p. 4

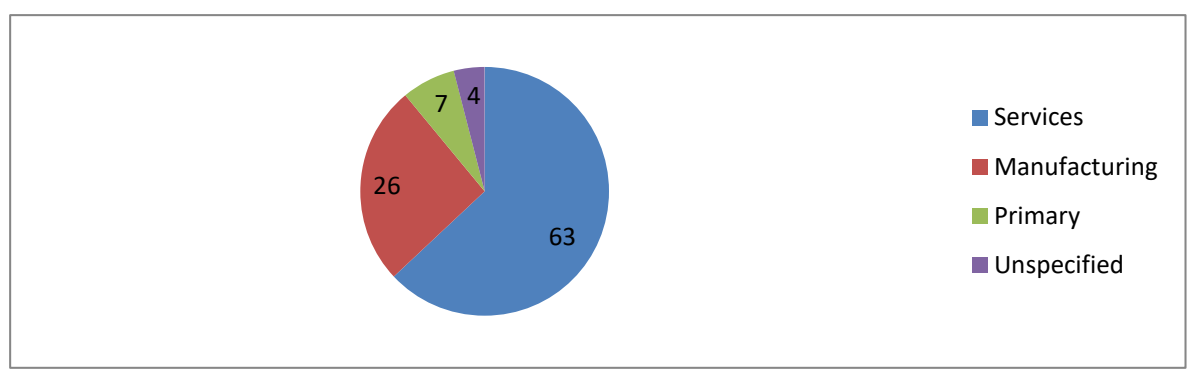

Diagram 4. The structure of FDI by the sectors of the economy (in \%)

Source: my own lay-out on the basis of World Investment Report 2018. Investment and New Industrial Policies. New York and Geneva: United Nations, pp. 7-8 
$63 \%$ of the overall number of FDI (see diagram 4 ). The second best was manufacturing (26\%), and the third best was the sector called primary (7\%). The remaining share fell on the unspecified industries (4\%).

\section{The determining factors of FDI}

FDI are the main factor of intensive development and modernization of economy (Chakrabarti, 2001, Blonigen, 2005, Siemiątkowski, 2005). FDI had the special role in this activity in developing (Asiedu, 2006, Jenkins, 2005) and transformation countries, such as Poland and the most accession's countries of the European Union (Wyrzykowska, 2010, p. 179, Rudnytska, 2015, Siemiątkowski, 2013, Luo, Xue, Han, 2010, Bevan, Estrin, 2004).

Planning and the successively making foreign direct investments is related with the occurrence and the analysis of multifarious factors and conditions jointly being the equivalent of the determinants specifying this activity (Sitek, 1997, p. 75). An entrepreneur, to properly plan the investment, must identify many properties of the investment environment in those realms which may contribute to the further success of an enterprise (Guillén, Garcia-Canal, 2009). Many researchers on that subject, in the light of the multitude of determinants, try to classify them. A relatively popular typology of the afore-mentioned determinants is the division into four groups: institutional, cultural, socio-economic and politico-legal ones (Bandelej, 1999 , pp. 8-14). Others classify the above factors into supply and demand ones (Tuselmann, 1999, p. 3), and still others - into geographic, economic, political and legal (Coskun, 2001, pp. 222-223).

In the early stages of the process of classifying the determinants of the foreign direct investments, one should differentiate between two of their general groups. The first one is constituted by the determinants contributing to making a decision as to making a direct investment abroad; or, to put it in another way, these the factors assisting such a decisions and determining taking such a step. The second distinguished group should be constituted by the determinants of the already made investment, that is the factors conditioning the current operations of foreign investors. It is only when we distinguish these two groups of determinants of FDI that we acquire the basis for any further typologies (Buckley, Clegg, Cross, Liu, Voss, \& Zheng, 2007).

The group of determinants causing or conditioning making a direct investments is usually subdivided into external and internal factors (Górniewicz, 2007, p. 101; Kolstad, Wiig, 2012). The internal determining factors stem from the nature of the operations of a given enterprise as well as from the resources the business enterprise owns and controls. On the other hand, the external determinants are not subject to control exercised by the business entity but they embrace the factors connected with its environment - both within the country and outside of it. Yet, applying the criterion of the direction of the flow of FDI, some economist divide the determining factors of investments into outward foreign direct investment and inward foreign direct investment into home economy (Górniewicz, 2013, pp. 64-66).

The first group of determinants cause the business enterprises to decide to "leave” the home economy and transfer the so-far business operations or its certain parts to the economies of the target countries (Ramasamy, Yeung, Laforet, 2012). The second group, however, embrace the determinants attracting foreign investors and encouraging them to make investments in the target country (Blalock, Gertler, 2008).

\section{The consequences of FDI}

The increasing significance of FDI in the world economy begs the question about benefits and dangers which result from them both to the country from which the capital outflows and to the country in which a given capital is located (Górniewicz, Siemiątkowski, 2006, pp. 161-168). Even though specifying all the positive and negative aspects of the flow of investments is certainly impossible, it is worth investigating those most important aspects, which might include:

1. balance of payments,

2. employment,

3. markets on which the product or the service is sold,

4. the resources of means of production,

5. GNP,

6. infrastructure,

7. technology,

8. competitiveness,

9. government budget,

10. legal provisions,

11. the image of a country on the international arena,

12. regional development,

13. the cost of running the business enterprise (Górniewicz, Siemiątkowski, 2007, pp. 273-275).

In the country to which the foreign capital flows, the inflow of FDI in the short run will positively influence the balance of payments. In connection with the probably increased inclination towards export of the joint ventures with the foreign capital, the balance of payments should also improve in the long run. Still, there are some serious misgivings to be considered. The first one is the possibility of transferring abroad the means that had been worked out, that is to native countries and the second is the growth in the import of the resources and the products necessary to run a business (Siemiątkowski, 2016a).

In the short run, the investments made abroad might give rise to the deterioration of the balance of payments in the country exporting capital because to start a new 
enterprise or the affiliate of the already existent foreign company (buying the existent enterprises or starting the new ones), what is necessary is the transfer of financial means. However, in the long run when enterprises start to make profits and the part of them will start flowing to the native country, its balance of payments will not improve (Budnikowski, 1997, p. 138, Safarians, 2016). In the countries which is a target of the capital flow, the inflow of FDI might directly cause new job vacancies in the emerging business enterprises. The investments coming from abroad might also indirectly influence the growth of employment in the target country through the increase of capital in the environment of the new business and also within the remit of the suppliers of semi-finished goods, raw materials of materials (Fosfuri, Motta, Rønde, 2001).

Still, there exists the danger that there will occur the decrease in employment in national enterprises, the latter of which might get pushed away by the foreign capital due to the expansion of foreign corporations. What is likely is the decrease in the production capacities in the business entities whose production is pushed out of the market and thus the decrease in employment might occur.

What is also possible is the decrease in employment contingent upon the form of foreign direct investments of the brownfield type. Taking over the already operative companies in the target country is usually connected with their restructuring. This, in turn, at its early stages involves downsizing. The determination of the influence of FDI on the employment rate in the country in which the capital originated is complicated. In the short run, this influence mainly depends on whether the outflowing capital would have been used if the very outflow had not occurred at all. If it would have been, the outflow would mean the loss of potential job vacancies. Still, if there is still in a given country the surplus of capital, this danger obviously does not exist (Górniewicz, 2007, p. 111, Siemiątkowski, 2016b).

Due to the inflow of FDI, the native performers might gain the access to the markets native to foreign investors (Agiomirgianakis, Asteriou, Papathoma, 2003, p. 6). There is still some serious danger relating to the loss of both the access to national market as well as foreign markets potentially inflicted upon the business entities operating within the economy which is a target of the investments.

From the perspective of the country exporting the capital, there are definitely more positive aspects related to investing abroad. First of all, FID should influence the acquisition of new markets and the expansion connected with the former. This fact is a primary incentive for making foreign direct investments. The additional benefit is the capability of increasing the competitiveness on native markets due to the lower cost of producing goods abroad, which, in turn, allows for expanding the national market.
The country exporting capital may be afflicted with the bad consequences of the outflow of FDI. One of bad consequences is the situation in which an investor transfers the entire business activity abroad simultaneously losing his or her shares in the national market. The extreme instance of this situation would be the entire loss of the market in one's native country (Górniewicz 2007, p. 112).

For the country admitting the inflow of the capital, the benefit will be obviously the acquisition of the new means worked out abroad. It will increase the capital in the target country, which - especially in the case of the developing country of Central-Eastern Europe - is insufficient for the rapid increase of the rate of development. Furthermore, what might prove to be a benefit is the acquisition of all the necessary experience by national workers employed in the affiliates of foreign business entities.

The country exporting the capital will obtain the new means of production but at the same time it might prove negative for economy. The national means of production might get pushed away by the cheaper ones originating in the country from which the capital moved. In the case of the target country of FDI, one might expect the increase in production in the business entities with foreign capital and thus the direct increase of the overall national product. What can also be manifested is the indirect influence of FDI on the global product in the target country. What is likely is the production growth in the cooperating enterprises as well as in the so-called business environment (Borensztein, De Gregorio, Lee, 1998, Hermes, Lensink, 2003).

As it usually is, the negative influence of foreign direct investments on the gross national product of the target country may manifest itself. It also manifests itself in pushing away the national production by the joint ventures with the foreign capital at their disposal; so, it even causes to the decrease of GNP (Mączyńska, 1999, pp. 89-90).

The production of subassemblies to the goods produced abroad and the profits of the citizens of the exporting country included in GNP are undoubtedly the positive effects for the country exporting the capital (Borensztein, De Gregorio, Lee, 1998). The negative phenomenon turns out to the probable decrease of the production in the country due to the transfer of its part across the border. From the perspective of the infrastructure in the target country receiving the foreign capital, it is difficult to pinpoint the dangers. One of them might be the fact that roads are worn out quicker; however, this is a natural consequence of business activity regardless of the origin of the capital. The benefits thereof seem all too obvious. The improvement of the situation with respect to infrastructure might be caused, for instance, by the implementation of the strategy of attracting the investors, the strategy 
usually encompassing the assumptions related to the development of the infrastructure around the areas which are the target of the very investments. Usually, the next step is the development of the infrastructure accompanying the development of the activities of joint ventures with the foreign capital share.

The influence of the inflow of FDI to a given country can have both positive and negative consequences in the realm of technological solutions (Wang, Blomström, 1992, Pao, Tsai, 2011). It may give rise to the inflow of ground-breaking and the so-called „dirty” (outmoded, capital-consuming and detrimental to the natural environment) technologies (Tamazian, Chousa, Vadlamannati, 2009).

Also in the case of the country exporting capital, one can point to both positive and negative aspects. Among the former, what should be enumerated is among others - creating the research and development base abroad, which in the long run might cause the transfer of technologies from the affiliate to the mother company, which is still quite unlikely (Blalock, Gertler, 2008). What is more likely is backing up the mother corporation with high-class specialists originating from the target country. In the recent years, such trends manifest themselves in the case of the transfer of doctors or IT specialist from the newly-joined member states of European Union to the so-called "Old Union" member states [the original 15 member states comprising European Union]. The country to which capital flows may count on the increase of competitiveness on its own market through the increasing number of potential competitors. There is still some fear that competitiveness will decrease because foreign capital may push away the national capital and even give rise to the monopolization of a given industry.

The capital „donor" must expect some decrease of competitiveness on his or her own market (and at best he can expect no changes) in the short run. However, in the long run, he or she may expect some improvements - especially when the goods produces in the foreign affiliate companies will reach the national market.

The influence of FDI on the government budget of the country to which the capital flows is multidimensional. As the first and foremost influence of the investments in this respect one can regard the potential growth of income to the budget due to the taxes paid in connection with the rise of new business entities (Bożyk, Misala, Puławski, 1998, p. 162). What is implied here is both direct taxes, paid by the business entity and the employees employed there, but also indirect taxes, related to the sales of produced goods. What is more, foreign direct investments, by contributing to the increase in the employment rate, directly relieves the government budget. It is because the amount of allowance from the public means is decreased; that is, the state now can pay the unemployed smaller allowances or later on - smaller social benefits. The increase of the number of business entities - regardless of whose property it is - will contribute to the increase of the income to the budget if not short-term, then definitely medium- or long-term.

Apart from the undeniably positive, as noted above, influences of the foreign direct investments on the government budget of the country to which the capital flows, some negative influences may be unfortunately pointed out too. The business enterprises with the foreign capital share may, wanting to compensate for the high cost of investing outside its home economy, avoid paying taxes in the target country. Such a mechanism may also be based on exaggerating cost of business operations or not revealing the real cost at all. Then, the budget of the country to which the capital flows will certainly make losses. Perhaps the proportions of such malpractice among the joint ventures with the foreign capital share is bigger than in the case of national business entities because the foreign companies have the greater capability of regulating cost by the contracts with the parent corporations. However, one should bear in mind that generally the majority of business entities strive for paying as little taxes as possible. The internally financed (only from the capital within one's native country) business enterprises also subscribe to the above "code" of behaviour.

Undoubtedly, the important area of influence exerted by direct investments on the economies of particular countries is the area of legislation (Busse, Hefeker, 2007). A particularly intense influence is manifested in the country to which the capital flows. Still, one should unequivocally state that good legislation is one of the indicators of the foreign capital inflow to the economy. Thus, legislation which restricts the operations of business entities automatically becomes the barrier for the foreign capital inflow (Górniewicz, Siemiątkowski, 2006, p. 176, Holburn, Zelner, 2010).

The area in which the undeniably positive consequences of the inflow of foreign direct investments is manifested is the prestige and the improvement of the image of the target economy on the international arena. The increased inflow of FDI causes the country to gain prestige in the eyes of managers, politicians and entreprenuers. The natural conclusion derived from the increased inflow of investments is being certain of the stability of a given economy and about the good conjuncture on a given market. The above factors entail the other ones in the form of the increased credibility of Polish economy, which results in, for instance, obtaining the better position in the international ratings of competitiveness. The effect of such phenomena might be even bigger inflow of investments, which, in turn, potentially contributes to the development of the entire economy.

The flow of foreign direct investment might exert the essential influence on the development of particular 
regions of economies to which the capital flows but also on the regions of the economies from which the capital flows out. In the case of the country to which the capital flows, what is particularly important is the proper pursuit of the policy of attracting foreign investments. That policy should favour investors in the areas which are economically lagging, which would allow for the acceleration of the process of equalizing the developmental levels in those regions. Encouraging investors might assume two different forms: offering the investment area with the developed infrastructure, erecting technological parks with the infrastructure, creating tax incentives etc.

One of the most important parametres of the economy is the cost of running business. It is also on this factor that the foreign direct investments have a bearing - both on the part of the country to which the capital flows and on the part of the country exporting capital. The positive influence of the target economy in this respect may be manifested in the consequences of the strategy of attracting foreign investors. The government, striving to encourage as many investors as possible to allocate the capital in the target country, will probably want to create the congenial conditions to run business for foreign investors - also with respect to cost. Thus, it is possible to decrease the financial burden of all the business entities. Simultaneously, the situation might occur in which the increased demand for service of the business environment will cause the increase of service prices, which as a result will give rise to the increased cost of running business as a whole (Zhorzholiani, 2019).

One of the consequences of the countries being a target of FDI is the fear of political consequences of the home economy being dominated by foreign owners representing (first and foremost the interest of their native countries). For example, in the highly developed countries such as Canada allocating significant part of American capital, there is the fear that in case of USA pursuing a policy of economic sanctions against any third countries, there might occur some pressure to include in this sort of action the foreign enterprises with the American capital share, which might prove inconsistent with the national interest of Canadians (Górniewicz, Siemiątkowski, 2006, p. 181).
On the other hand, in the developing countries being rich in mineral materials, there are commonly shared fears that FDI and in particular the business activities of big concerns might contribute to excessive exploitation of those materials and inconsistency with the long-term interest of the countries endowed with the said materials. Still, in the developing countries having the aspirations of becoming the continental hegemonies (e.g. Brazil, India or Iran) what is restricted is the share of foreign capital in business companies (generally to $50 \%$ and sometimes even to 0 ) (Budnikowski 2001, pp. 153-154, Cui, Jiang, 2012).

\section{Conclusions}

Foreign direct investments constitute the important part of contemporary international flows of means of production. What testifies to it is the relatively big scale of that phenomenon. Despite a certain collapse caused by the world economic crisis the level of FDI is still high.

Although FDI flows into all the continents, their respective amounts vary. Generally, the greatest number of FDI was allocated to Asian, European and North American countries. The investments generally skipped the poorly developed areas, which particularly relates to Africa. One should expect that in the forthcoming years, the proportions of foreign direct investments will steadily grow. The reasons for this phenomenon should be subscribed to the economy being increasingly receptive and the processes of globalization still proceeding.

The important issue connected with FDI are the consequences which occur due to their flow. They might be positive or negative both for the countries exporting capital and the for the countries to which the capital flows. The main advantages and the main dangers usually embrace what follows: the influence of FDI on the balance of payments, employment rate, getting new markets on which the product can be sold, the resources of means of production, gross national product, infrastructure, technology, competitiveness, government budget and the development of particular regions.

\section{References:}

Agiomirgianakis, G., Asteriou, D., \& Papathoma, K. (2003). The Determinants of Foreign Direct Investment: A Panel Data Study for the OECD Countries. London: City University London, Department of Economics, Discussion Paper Series, no. 03/06.

Asiedu, E. (2006). Foreign direct investment in Africa: The role of natural resources, market size, government policy, institutions and political instability. World Economy, 29(1), pp. 63-77.

Bandelj, N. (1999). Embedded Economies: Determinants of Foreign Direct Investment in Central and Eastern Europe. Princeton: UNCTAD.

Bevan, A.A., \& Estrin, S. (2004). The determinants of foreign direct investment into European transition economies. Journal of Comparative Economics, 32(4), pp. 775-787.

Blalock, G., \& Gertler, P.J. (2008). Welfare gains from Foreign Direct Investment through technology transfer to local suppliers. Journal of International Economics, 74(2), pp. 402-421. 
Blonigen, B.A. (2005). A review of the empirical literature on FDI determinants. Atlantic Economic Journal, 33(4), pp. 383-403.

Borensztein, E., De Gregorio, J., \& Lee, J.-W. (1998). How does foreign direct investment affect economic growth? Journal of International Economics, 45(1), pp. 115-135.

Bożyk, P., Misala, J., \& Puławski, M. (1998). Międzynarodowe stosunki ekonomiczne. Warszawa: PWE.

Buckley, P.J., Clegg, L.J., Cross, A.R., Liu, X., Voss, H., \& Zheng, P. (2007). The determinants of Chinese outward foreign direct investment. Journal of International Business Studies, 38(4), pp. 499-518.

Budnikowski, A. (1997). Międzynarodowe obroty czynnikami produkcji. In: A. Budnikowski and E. KaweckaWyrzykowska (Eds.), Międzynarodowe stosunki gospodarcze. Warszawa PWE.

Budnikowski, A. (2001). Międzynarodowe stosunki gospodarcze. Warszawa: PWE.

Busse, M., \& Hefeker, C. (2007). Political risk, institutions and foreign direct investment. European Journal of Political Economy, 23(2), pp. 397-415.

Chakrabarti, A. (2001). The determinants of foreign direct investment: Sensitivity analyses of cross-country regressions. Kyklos, 54(1), pp. 89-114.

Coskun, R. (2001). Determinants of Direct Foreign Investment in Turkey. European Business Review, 13(4).

Cui, L., Jiang, F. (2012). State ownership effect on firms' FDI ownership decisions under institutional pressure: A study of Chinese outward-investing firms. Journal of International Business Studies, 43(3), pp. 264-284.

Fosfuri, A., Motta, M., \& Rønde, T. (2001). Foreign direct investment and spillovers through workers' mobility. Journal of International Economics, 53(1), pp. 205-222.

Górniewicz, G. (2013). Determinanty i konsekwencje bezpośrednich inwestycji zagranicznych. Bydgoszcz: Uniwersytet Kazimierza Wielkiego w Bydgoszczy.

Górniewicz, G., \& Siemiątkowski P. (2007). Bezpośrednie inwestycje zagraniczne na świecie. Ekonomista, 3.

Górniewicz, G., \& Siemiątkowski, P. (2006). Wprowadzenie do międzynarodowych przepływów kapitału. Toruń: Towarzystwo Organizacji i Kierownictwa - Stowarzyszenie Wyższej Użyteczności "DOM ORGANIZATORA"

Górniewicz. G. (2007). Konsekwencje międzynarodowych przepływów kapitału dla gospodarki światowej ze szczególnym uwzględnieniem Polski. Bydgoszcz: Wydawnictwo Uniwersytetu Kazimierza Wielkiego.

Guillén, M. F., \& Garcia-Canal, E. (2009). The American model of the multinational firm and the "new" multinationals from emerging economies. Academy of Management Perspectives, 23(2), pp. 23-35.

Hermes, N., Lensink, R. (2003). Foreign direct investment, financial development and economic growth. Journal of Development Studies, 40 (1), pp. 142-163.

Holburn, G. L. F., \& Zelner, B. A. (2010). Political capabilities, policy risk, and international investment strategy: Evidence from the global electric power generation industry. Strategic Management Journal, 31(12), pp. 1290-1315. Investment Trends Monitor. (2020). Retrieved from: https://unctad.org/en/PublicationsLibrary/ diaeiainf2020d1_en.pdf

Jasiński, B., \& Mesjasz, L. (1997). Rola finansowania zewnętrznego w procesie restrukturyzacji przemysłu krajów CEFTA. In Zadłużenie zewnętrzne a rozwój przemysłu kraju dłużniczego. Kraków: Akademia Ekonomiczna.

Jenkins, R. (2005). Globalization, Corporate Social Responsibility and poverty. International Affairs, 81(3), pp. 525-540.

Kolstad, I., \& Wiig, A. (2012). What determines Chinese outward FDI? Journal of World Business, 47(1), pp. $26-34$. Luo, Y., Xue, Q. \& Han, B. (2010). How emerging market governments promote outward FDI: Experience from China. Journal of World Business, 45(1), pp. 68-79.

Marszałek-Kawa, J., and Plecka, D. (Eds.) (2019). The Dictionary of Political Knowledge. Toruń: Wydawnictwo Adam Marszałek.

Mączyńska, E. (1999). Bezpośrednie inwestycje zagraniczne. Światowe i lokalne czynniki dynamizujące. Ekonomista, 1-2.

Meyer, K. E., \& Sinani, E. (2009). When and where does foreign direct investment generate positive spillovers A meta-analysis. Journal of International Business Studies, 40(7), pp. 1075-1094.

OECD. (2008). Benchmark Definition of Foreign Direct Investment. Retrieved from: https://www.oecd.org/ investment/fdibenchmarkdefinition.htm

Pao, H.-T., \& Tsai, C.-M. (2011). Multivariate Granger causality between CO2 emissions, energy consumption, FDI (foreign direct investment) and GDP (gross domestic product): Evidence from a panel of BRIC (Brazil, Russian Federation, India, and China) countries. Energy, 36(1), pp. 685-693).

Ramasamy, B., Yeung, M., \& Laforet, S. (2012). China's outward foreign direct investment: Location choice and firm ownership. Journal of World Business, 47(1), pp. 17-25.

Redo, M., \& Siemiątkowski, P. (2017). Zewnętrzne bezpieczeństwo finansowe państwa. Toruń: Uniwersytet Mikołaja Kopernika. doi: http://dx.doi.org/10.12775/TIS.2017.100

Rudnytska, U. (2015). The prospects for Baltic - Black Sea cooperation in the context of current Russian-Ukrainian relations, Torun International Studies, 1(8), doi: 10.12775/TIS.2015.008 
Safarians, Y. (2016). Trade cooperation and Austrian investment activity in Ukraine. Torun Interational Studies, 1(9), 43-55. doi: http://dx.doi.org/10.12775/TIS.2016.004

Siemiątkowski, A. (2016b). The influence of transnational corporations on society's safety based on activity of Amazon.com in Poland and Great Britain. Torun International Studies, 1(9), 131-140. doi: http://dx.doi.org/10.12775/TIS.2016.012

Siemiątkowski, P., Tomaszewski, P., Marszałek-Kawa, J., \& Gierszewski, J. (2020). The Financing of Renewable Energy Sources and the Level of Sustainable Development of Polands Provinces in the Area of Environmental Order. Energies, 13(21), 5591. doi: 10.3390/en13215591

Siemiątkowski, P. (2013). British foreign direct investments in the light of the World. Torun International Studies, 1(6), 55-66. doi: http://dx.doi.org/10.12775/TIS.2013.006

Siemiątkowski, P. (2016a). The influence of the global economic crisis on the international investment position of Eropean Union member states. Torun International Studies, 1(9), 103-110. doi: http://dx.doi.org/10.12775/ TIS.2016.009

Sitek, E. (1997). Determinanty bezpośrednich inwestycji zagranicznych. Częstochowa: Politechnika Częstochowska.

Tamazian, A., Chousa, J. P., \& Vadlamannati, K. C. (2009). Does higher economic and financial development lead to environmental degradation: Evidence from BRIC countries. Energy Policy, 37(1), pp. 246-253.

Tuselmann, H. J. (1999). German Direct Foreign investment in Eastern and Central Europe: Relocation of German Industry? European Business Review, 99(6).

Wang, J.-Y., \& Blomström, M. (1992). Foreign investment and technology transfer. A simple model. European Economic Review, 36(1), pp. 137-155.

World Investment Report 2013 (2013). Global Value Chains: Investment and Trade for Development. New York and Geneva: United Nations.

World Investment Report 2015 (2015). Reforming International Investment Governance. New York and Geneva: United Nations.

World Investment Report 2018 (2018). Investment and New Industrial Policies. New York and Geneva: United Nations.

World Investment Report 2019 (2019). Key Messages and Overview. Geneva: United Nations.

Wyrzykowska, M. (2010). Bezpośrednie inwestycje zagraniczne w "nowych krajach" Unii Europejskiej na przykładzie Polski. Torun International Studies, 1(3), 179-193. doi: http://dx.doi.org/10.12775/TIS.2010.013

Zhorzholiani, T. (2019). The assessment of corruption impact on the inflow of foreign direct investment (in the case of Georgia, Armenia and Azerbaijan). Torun International Studies, 1(12), 181-192. doi: http://dx.doi.org/10.12775/TIS.2019.012 